$12-30-1996$

\title{
The Astonishing Year(s) of 1996: A Confusion of Tongues and Alphabetical Camels the First Time as Tragedy
}

Kenneth Lasson

University of Baltimore School of Law, klasson@ubalt.edu

Follow this and additional works at: http://scholarworks.law.ubalt.edu/all_fac

Part of the Legal History Commons, and the Religion Law Commons

\section{Recommended Citation}

The Astonishing Year(s) of 1996: A Confusion of Tongues and Alphabetical Camels the First Time as Tragedy, The

This Editorial is brought to you for free and open access by the Faculty Scholarship at ScholarWorks@University of Baltimore School of Law. It has been accepted for inclusion in All Faculty Scholarship by an authorized administrator of ScholarWorks@University of Baltimore School of Law. For more information, please contact snolan@ubalt.edu. 


\section{Related Articles}

Who are these people with whom we are at war? It

is...

January 24, 1991

Letters To The Editor

April 27, 2003

Hopkins researcher cautins on risks of caffeine addiction...

September 29, 1996

Addict questions drug sentencing

November 21, 1993

Recovering addicts retreat to Harford

March 7, 2001

\section{Find More Stories About}

Abraham

Nimrod

\section{The astonishing year(s) of 1996: a confusion of tongues and alphabetical camels The first time as tragedy}

$\begin{array}{lll}\text { Recommend } & \left\{\begin{array}{l}0 \\ \text { Tweet }\end{array}\right. \\ & \bullet \vdots & 0 \\ & \bullet & \mathbf{G}+1\end{array}$

December 30, 1996 | By Kenneth Lasson

IN MANY WAYS the year 1996 -- the one Before the Common Era, before the birth of Jesus -- marked the destiny of humankind as none other. The Great Flood had receded 340 years earlier. Noah and his children were still alive. Abraham was a middle-aged man. All the world's people were concentrated in Babylonia (now Iraq), speaking a common language, living as one nation under idols.

At least they did until Nimrod came along and subjugated the Babylonians. Some say he began as a selfless spirit, only later to be corrupted by power and turn into the first classic despot. He became a monarch with a mission, which was not only to rule the world but to deny any divine involvement with it. The Deluge, he claimed, was a natural and predictable event which occurred every 1,656 years.

Such irreverence was nothing new to Nimrod. A half-century earlier he had encouraged Abraham, who'd publicly renounced idolatry even though his father manufactured and sold graven images: how ridiculous, he reasoned, to worship clay figures that had been made the day before! Thus did Nimrod have Abraham thrown into a fiery furnace, from which, according to Midrashic legend, he emerged unscathed. Unlike Nimrod, Abraham eschewed power in favor of teaching ethics and morality to his people.

In the intervening years Nimrod concerned himself with the building of great cities as testimony to his own power and invincibility. And in 1996 (B.C.E.) he is said to have commissioned the mother of all monuments -- the Tower of Babel -from which he could wage war against the Heavens. Yes, echoed the people: "Come, let us build a tower with its top in the heavens, and let us make a name for ourselves." (Genesis 11: 4)

For this deed, the Bible tells us, mankind was scattered over the face of the earth to form no fewer than 70 different nations, each with its own language and self-interest. Strife and discord ensued.

Close to two millenniums later the miracles of science and technology have once again made the world a smaller place but little has changed to bring people together as a unified moral force. What should be a common quest for peace and justice is confounded by greed and ego. There is little love lost between blacks and whites, Irishmen and Englishmen, Palestinians and Jews.

Which makes all the more remarkable the miracle of America, where respect for and protection of individual liberty continues to be the essence of our national psyche. Although all good citizens are concerned about the country's major ills -- violent crime, poor public education, drug addiction -- none would likely trade their native freedom to live anywhere else.

In the 1996 just concluding, few Americans can fathom why Saddam Hussein is still in power in Iraq (once Babylonia), why Serbs and Croats are at each other's throats, why Russians are having such a hard time adjusting to democracy, or why oil-wealthy Arabs with vast land-holdings would like to see minuscule Israel reduced to dust.

Freedom of conscience is more alive and well here and now in the United States of America than perhaps anywhere else at any other time in the history of the world.

Were Nimrod to seek power over our dominion, he'd be run out of town on a rail.

Had Abraham not been destined for the Promised Land, this is where he'd have found religious liberty. May others have it so good in 1997.

Kenneth Lasson teaches civil liberties at the University of Baltimore School of Law.

Pub Date: $12 / 30 / 96$

From the Web

Sponsored Links

Maryland: Drivers Are Stunned By This New Rule

Provide Savings Insurance Quotes

Americans Use Program To Cut Years Off Credit Card Payments LendingTree

Why This Shirt Company Is Causing so Many Guys to Switch Proper Cloth 
How I Finally Understood My 401(k)... in 10 minutes

Mint | Future Advisor

10 Clothes Middle-Aged Women Should Avoid

Lifescript

See The Online Furniture Store That Has Retailers Worried

Wayfair

Are you a strategic thinker? Test your skills with millions of addicted players! Sparta - Free Online Game

This Service in Baltimore is Changing the Way People Cook at Home HelloFresh

by Taboola

MORE:

A tale of customer service, justice and currency as funny as a $\$ 2$ bill

Family's bad fortunes propelled Thomas to better life How to treat bone spurs

He was born to coach

Harriet Tubman honored as a saint

Index by Keyword | Index by Date | Privacy Policy | Terms of Service

Please note the green-lined linked article text has been applied commercially without any involvement from our newsroom editors, reporters or any other editorial staff. 